\title{
GOLD RECOVERY OF REFRACTORY SULFIDE CONCENTRATES USING DIRECT CYANIDE LEACHING WITH NITRITE AS AN OXIDANT
}

\author{
PEROLEHAN EMAS DARI KONSENTRAT REFRAKTORI \\ SULFIDA DENGAN SIANIDASI LANGSUNG MENGGUNAKAN \\ OKSIDAN NITRIT
}

\author{
SURATMAN \\ R\&D Centre for Mineral and Coal Technology \\ Jalan Jenderal Sudirman 623 Bandung 40211 \\ Phone. (+6222) 6030483. Fax. (+6222) 6003373 \\ e-mail: suratman@tekmira.esdm.go.id
}

\begin{abstract}
The problem of refractory sulfide gold ore that has a gold recovery less than $50 \%$ when direct cyanidation applied, still exists until now. It needs oxidative pretreatment for cyanidation to be effective in gold recovery the objective of this study is figuring out the effect of sodium nitrite as an oxidizing reagent on cyanidation of refractory gold ore. Cyanide leaching of the concentrate was performed at $20 \%-w / w$ of solid (500 gram of refractory sulfide gold ore concentrate) in a 2.5 -liter glass reactor with aeration and stirred at $250 \mathrm{rpm}$. Leach solutions were prepared using deionized-distilled water at the prescribed concentration of reagents. Recovery of gold increased gradually to its maximum value of $93.05 \%$ as the value of cyanide strength increased from 0.8 to $1.2 \%$ and the addition of sodium nitrite raise to $1.2 \mathrm{M}$. No improvement for further addition of nitrites. This introduction of new hydrometallurgical pre-treatment process has given more option for treating refractory ores.
\end{abstract}

Keywords: refractory gold ore, leaching, cyanide, nitrite, oxidant

\begin{abstract}
ABSTRAK
Permasalahan bijih emas refraktori sulfidis yang mempunyai peroleh emas lebih kecil dari 50\% bila diolah dengan proses sianidasi langsung, masih terjadi hingga saat ini. Bijih jenis ini memerlukan praolahan oksidatif dalam proses sianidasi supaya perolehan emasnya menjadi efektif. Tujuan penelitian ini adalah menelaah pengaruh natrium nitrit sebagai bahan oksidatif pada sianidasi bijih emas refraktori untuk meningkatkan perolehan emasnya. Kondisi pelindian menggunakan 20\% padatan umpan yang diaduk pada kecepatan $250 \mathrm{rpm}$. Larutan pelindi menggunakan sianida yang dilarutkan dalam air terdestilasi bebas ion. Perolehan emas bertambah secara bertahap sampai mencapai $93,05 \%$ sejalan dengan peningkatan konsentrasi sianida dari 0,8 sampai 1,2\% dan konsentrasi natrium nitrit sebesar 1,2 M. Hasil penelitian ini telah memberi pilihan baru bagi proses praolahan bijih emas refraktori sulfidis melalui jalur proses hydrometalurgi.
\end{abstract}

Kata kunci: bijih emas refraktori, pelindian, sianida, nitrit, oksidan

\section{INTRODUCTION}

Refractory sulfide gold ores are characterized by yield poor gold recovery in direct conventional cyanide leaching. That problem is an old and still existing problem until this time. The refractory sulfide gold ores in which gold is surrounded by sulfide minerals, oxidative pretreatment of the ore is important to oxidize the sulfides and expose the gold (Carrillo-Pedroza et al., 2012; Hasab, Rashchi and Raygan, 2013; Faraz et al., 2014). 
At present, the use of cyanide for gold extraction still remains as a common ligand of gold because it has some advantages being capable of extracting gold from the ore. The cyanide gold ligand has a great effectiveness for gold dissolution and selectivity for gold over other metals, compared to other ligands such as halides, thiosulphate, thiourea, and thiocyanate. (De Michelis et al., 2013; Breuer, 2015; Gökelma et al., 2016).

The gold complexes in aqueous solution can exist in one of two oxidation states, the aurous $(+1)$ or the auric $(+3)$, which are expressed in the cyanide complexes of gold(I) and gold(III) of $\mathrm{Au}(\mathrm{CN})_{2}{ }^{-}$and $\mathrm{Au}(\mathrm{CN})_{4}{ }^{-}$, respectively. The gold (I) and gold (III) compounds have an important role, as a basic principle for extractive metallurgy of gold. The number coordination and stability of these complexes, for co-ordination number of gold (I) is 2 and that of gold (III) is 4. For the success of the gold cyanidation on its application is restricted by several factors of the characteristics of gold ore or gold mineralization. But no doubt by the extractive metallurgist that the gold(I) complex of the greatest importance which is extremely stable aurocyanide anion and is the predominant gold species present in cyanide leach liquors. The thermodynamic data of the potential-pH equilibrium diagram for the $\mathrm{Au}-\mathrm{CN}-\mathrm{H}_{2} \mathrm{O}$ system is presented Figure 1.

From Figure 1, it can be seen that aurocyanide anion or $\mathrm{Au}(\mathrm{CN})_{2}^{-}$has a stable property and as the predominant gold species in cyanide leach liquors. This condition will be achieved and will provide an optimal yield of gold cyanidation process; if the presence of gold in the ore is exposed gold or liberated gold.

Refractory gold ores are those that do not yield high gold recoveries in conventional cyanide leaching circuits, even when the ore is finely ground. The degree of refractoriness has been classified based on the proportion of gold recovered (Table 1) (Marsden and House, 2009).

Table 1. Classification of refractory gold ores based on the degree of gold recovery

\begin{tabular}{cc}
\hline $\begin{array}{c}\text { Classification of } \\
\text { refractory gold ores }\end{array}$ & Recovery of gold \\
\hline Free milling & More than $95 \%$ \\
Mildly refractory & $80-95 \%$ \\
Moderately refractory & $50-80 \%$ \\
Highly refractory & Less than $50 \%$ \\
\hline
\end{tabular}

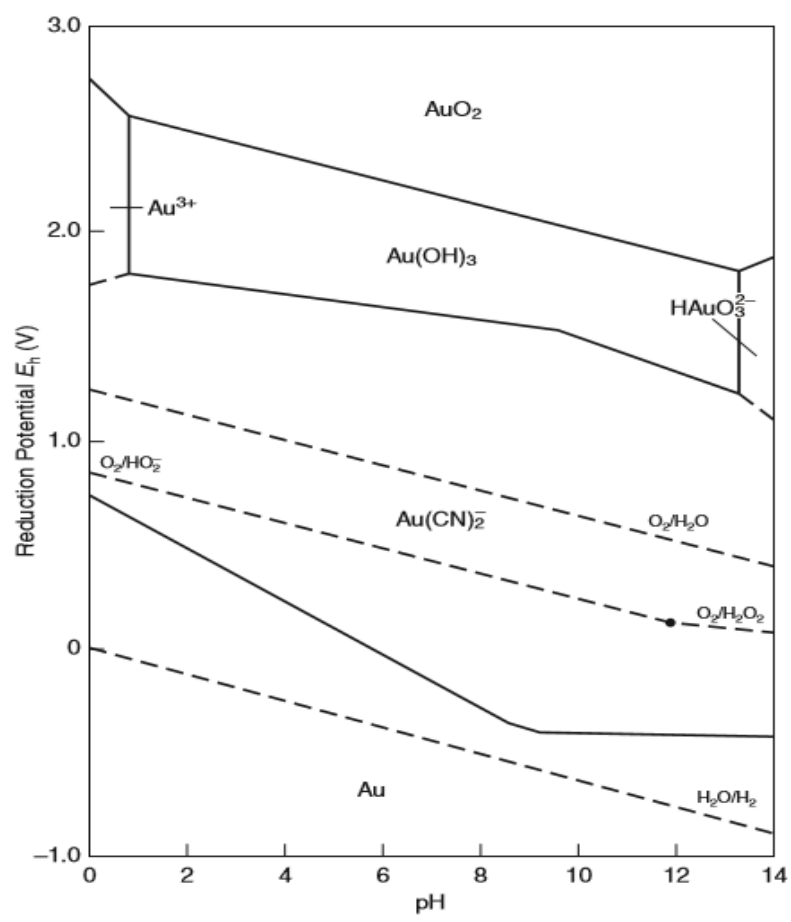

Figure 1. Potential-pH diagram for the system of $\mathrm{Au}-\mathrm{H}_{2} \mathrm{O}-\mathrm{CN}^{-}$at $25^{\circ} \mathrm{C}$ 
The gold in refractory sulfide gold ores is surrounded by sulfide minerals, particularly due to the encapsulation of fine particles of gold in iron sulfide minerals such as pyrite, pyrrhotite, chalcopyrite, sphalerite, and arsenopyrite (Badri and Zamankhan, 2013; Asamoah, Amankwah and Addai-Mensah, 2014; Mesa Espitia and Lapidus, 2015; Muravyov, Fomchenko and Kondrat'eva, 2015). Various methods had been investigated in an attempt to enhance gold recovery from the refractory sulfide gold ores. An oxidative pretreatment of the ore is essential to oxidize the sulfides and expose gold. The conventional methods of extraction of refractory sulfide gold ores usually follow roasting-leaching and electrowinning steps. Roasting is one oxidative pretreatment technique for sulfide minerals through pyrometallurgy route, also known as pyrometallurgical oxidation. The process is carried out at a high temperature between $500^{\circ} \mathrm{C}$ and $700^{\circ} \mathrm{C}$ (McHugh, Balliett and Mozolic, 2008; Anonymous, 2012). In this regard, roasting is generally carried out before cyanidation and in the process, roasting inevitably will emit a certain amount of toxic and harmful gases. It involves a thermal gas-solid reaction in which sulfides and sometimes organic carbon are oxidized to $\mathrm{SO}_{2}$ and carbon dioxide $\left(\mathrm{CO}_{2}\right)$. Therefore, roasting will be encountering with environmental limitations that very strict at the present, and also the limited availability of the energy making it being a high cost.

In order to solve environmental pollutions and other limitations, many researchers have been researching to develop other methods of oxidative pretreatment of refractory sulfide gold ore for many years. An aqueous oxidation based on the principle of hydrometallurgy process is one of the methods of pretreatment where the sulfur species tend to oxidize to the less harmful sulfate form. There are several aqueous oxidation techniques prior to cyanidation to treat refractory gold ores: chemical (chlorine, hypochlorite, chlorates, perchlorates, ozone, oxygen, and sulfuric acid) or electrochemical oxidation, pressure leaching, and bacterial leaching (Li et al., 2006; Hu, Wang and Wei, 2012; Valenzuela, Valenzuela and Parga, 2013).

The development of this research field has made the hydrometallurgical processes of direct leaching of sulfide gold ores and concentrates becomes more attractive because gold extraction from the ore by cyanidation can only be useful if gold present can be economically recovered with high efficiency.

One application of hydrometallurgical processes of direct leaching of sulfide mineral concentrates which have been applied commercially is for extraction of molybdenum from molybdenite concentrate by using nitric acid as an oxidizing reagent ( $\mathrm{Li}, 2009$; Khoshnevisana and Yoozbashizadeha, 2012). Based on the literature review, all the refractory sulfide ores which have studied so far are only through pretreatment the ores. On the other hand, no information exists about direct cyanidation of refractory gold ore using sodium nitrite as an oxidant. It is known that sodium nitrite is more oxidative than nitric acid based on its thermodynamics data. Sodium nitrite can oxidize sulfide to sulfate in alkaline conditions as a necessary condition for the cyanidation process. The objective of this study is to observe the possibility of direct cyanidation and also the optimization of oxidative pretreatment process using aqueous oxidation with the addition of nitrite as an oxidant on the recovery of gold from refractory gold ore.

\section{METHODOLOGY}

\section{Sample Preparation}

The refractory sulfide gold ore used in this study was the flotation concentrate of refractory sulfide gold ore, provided by PT USA, a small-scale gold mining in West Java. For experimental tests, the ore sample was prepared by grinding and sieving and dried in air at room temperature for 24 hours. The refractory gold ore concentrate was ground down to $-74 \mu \mathrm{m}$ using laboratory ball mill and steel balls. The grinding process results in $80 \%$ passing particles size of $74 \mu \mathrm{m}$.

The particle size distribution of ground samples was determined using Retsch wet vibratory sieve shaker. These were then split to obtain several representative sub-samples as leaching test samples and analyzed to determine their chemical composition.

Screening assays were performed on $1.0 \mathrm{~kg}$ samples using standard Tyler sieves, with mesh openings of 80 mesh, 120 mesh, 140 
mesh and 200 mesh, and a wet vibratory sieve shaker. A precision analytical scale with an accuracy of $1 \mathrm{mg}$ was used to weigh the materials retained by the sieves.

\section{Leaching Experiment}

The leaching experiments were conducted in a jacketed glass reactor with working volume of 2.5 liters equipped with a four-necked round-bottomed glass lid which was mechanically Teflon stirred with a paddle stirrer, condenser, thermometer, glass funnel for adding the solid sample and chemical reagent. The temperature in the reactor was maintained by heat exchange with a thermostat connected to the circulation of thermo-fluid silicon oil (SilOil). Figure 2 shows a schematic diagram of leaching equipment used for the experiment.

To study the effect of adding nitrite to the direct cyanide leaching of refractory sulfide gold ore, the experiments are carried out by dividing into multiple stages of leaching experiment. The first stage, an experiment to study the effect of the addition of nitrite to the cyanidation process in the form of sodium nitrite $\left(\mathrm{NaNO}_{2}\right)$ with varying concentrations of sodium nitrite (0.6 to 2.0 molar). For this stage of direct cyanide leaching, it used cyanide strength of $0.6 \%$ and are made constant for all experiments. The second stage was optimization of direct cyanide leaching of refractory sulfide gold ore with selecting a certain quantities concentration of sodium nitrite by referring to the acquisition of the first stage of experiment results. The second stage used variations of cyanide strength of 0.8 to $1.8 \%$. The retention time of oxidation pretreatment and direct cyanide leaching was fixed for all experiments: for 10 hours for the process of oxidation pretreatment and 20 hours for the cyanidation process.

Cyanide leaching of the concentrate was performed at $20 \%-\mathrm{w} / \mathrm{w}$ of solid (500 gram of refractory sulfide gold ore concentrate) in a 2.5-liter glass reactor with aeration and stirred at $250 \mathrm{rpm}$. Leach solutions were prepared using deionized-distilled water at the prescribed concentration of reagents. The leaching equipment was used for simultaneous oxidation pretreatment and cyanidation in the same reactor. The calculated volumes of distilled water and $\mathrm{NaNO}_{2}$ were added to the glass reactor and heated up to the selected temperature. A summary of cyanide leaching conditions is shown in Table 2.

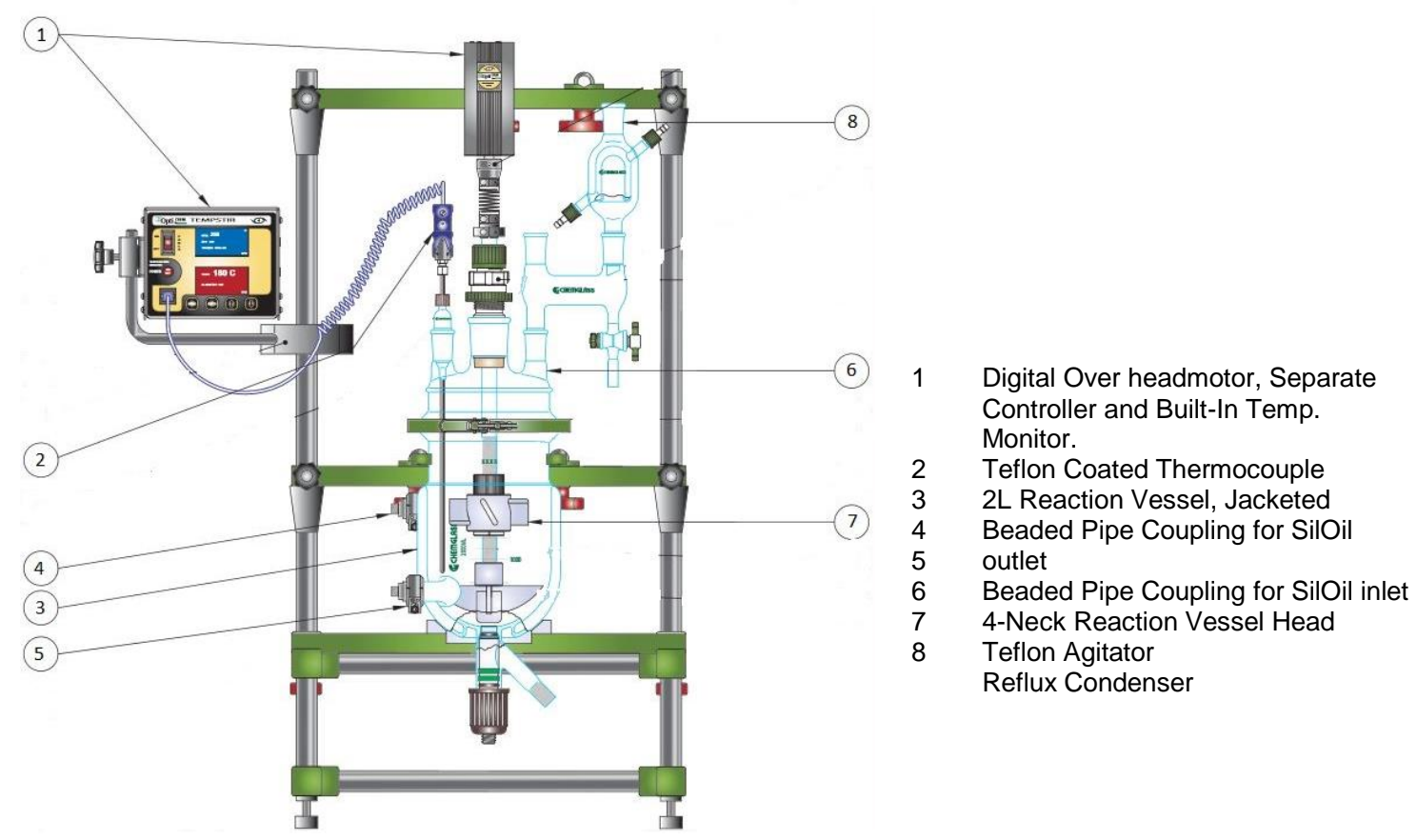

Figure 2. Experimental set-up of glass reactor for oxidation and cyanidation 
Table 2. Experimental conditions for cyanide leaching of the ore

\begin{tabular}{ll}
\hline \multicolumn{1}{c}{ Parameter } & \multicolumn{1}{c}{ Amount } \\
\hline Sample mass $/ \mathrm{g}$ & 500 \\
Particle size, d80 $\mu \mathrm{m}$ & $74 \mu \mathrm{m}$ \\
Solids content, w/w, \% & $20 \%$ \\
$\mathrm{pH}(\mathrm{NaOH})$ & 12 \\
Agitation, rpm & 250 \\
Cyanide strength $(\mathrm{KCN})(\%)$ & $0.8-1.8 \%$ \\
Leaching time, hour & 20 \\
Pretreatment temperature, oC & $700 \mathrm{C}$ \\
Cyanidation & Room temperature \\
Aeration, I/min & 0,5 \\
NaNO2 concentration, $\mathrm{mol} / \mathrm{L}$ & $0.8 ; 1.0 ; 1.2 ; 1.4 ; 1.6 ; 1.8 ; 2.0$ \\
\hline
\end{tabular}

Effect of sodium nitrite on cyanide leaching was examined at $0.8-2.0 \mathrm{~mol} / \mathrm{L} \mathrm{NaNO}$. Also, gold and silver extractions were investigated by cyanidation at different cyanide strength and sodium nitrite concentrations. Over the leaching period, samples were removed and analysed for $\mathrm{Au}$ and $\mathrm{Ag}$ using an atomic absorption spectroscopy (AAS-Perkin Elmer). On completion of leaching, residues were also analysed. Metal extractions were determined based on the residue analysis.

\section{RESULTS AND DISCUSSION}

\section{Characterization of ore concentrate sample}

Particles size analysis of the gold ore ground sample shows that the particle size distribution of smaller than $74 \mu \mathrm{m}$ ( 200 mesh) was more than $80 \%$ as presented in Table 3 .

Characterization of the ore sample was performed by the analytical method of X-ray diffraction (XRD) to determine its mineral composition, and the results are in Figure 3 and Table 4. From Figure 3, it can be seen that the major components of the concentrate ore sample are quartz $\left(\mathrm{SiO}_{2}\right)$, pyrite $\left(\mathrm{FeS}_{2}\right)$, and kaolinite $\left(\mathrm{Al}_{2} \mathrm{Si}_{2} \mathrm{O}_{5}(\mathrm{OH})_{4}\right)$. Sphalerite $(\mathrm{Fe}$, $\mathrm{ZnS})$ and mooihoekite $\left(\mathrm{Cu}_{9} \mathrm{Fe}_{9} \mathrm{~S}_{16}\right)$ constituted the minor minerals of the concentrate. Small amounts of chalcopyrite $\left(\mathrm{CuFeS}_{2}\right)$ and arsenopyrite (FeAsS) were also detected. More than $90 \%$ of the minerals were separated from each other. Gold was not observable in this concentrate because of its small amount.

Table 4. Major mineral composition of the leaching test sample

\begin{tabular}{lc}
\hline \multicolumn{1}{c}{ Mineral } & Mass-\% \\
\hline Quartz $\left(\mathrm{SiO}_{2}\right)$ & 66.6 \\
Pyrite $\left(\mathrm{FeS}_{2}\right)$ & 11.8 \\
Arsenopyrite $(\mathrm{FeAsS})$ & 1.9 \\
Sphalerite $(\mathrm{Fe}, \mathrm{ZnS})$ & 4.4 \\
Chalcopyrite $(\mathrm{CuFeS})$ & 1.8 \\
Mooihoekite $\left(\mathrm{Cu}_{9} \mathrm{Fe}_{9} \mathrm{~S}_{16}\right)$ & 3.1 \\
Kaolinite $\left(\mathrm{Al}_{2} \mathrm{Si}_{2} \mathrm{O}_{5}(\mathrm{OH})_{4}\right)$ & 10.3 \\
\hline
\end{tabular}

The elemental analysis of the ores was determined using two methods of chemical analysis. X-ray fluorescence (XRF) was used to analyze the concentration of the major element. Meanwhile, gold and silver were analysed by fire assay and atomic-absorption spectroscopy (AAS). The results of element analysis were presented in Table 5 . As shown in this Table, the leaching test sample contained 9.35 ppm Au and 148 ppm Ag.

Table 3. Particle size distribution of gold ore sample for leaching experiment

\begin{tabular}{ccccc}
\hline \multirow{2}{*}{ Sieve No. } & \multicolumn{4}{c}{ Particle size distribution Analysis } \\
\cline { 2 - 5 } & Wt $(\mathrm{g})$ & $\%-\mathrm{Wt}$ & $\mathrm{Wt}(\mathrm{g})$ & Test-2 \\
\cline { 2 - 5 }+ Test-1 & 42 & 7 & 58 & 7 \\
$-80+120$ mesh & 22 & 4 & 30 & 4 \\
$-120+140$ mesh & 12 & 2 & 14 & 2 \\
$-140+200$ mesh & 26 & 4 & 26 & 4 \\
-200 mesh & 522 & 84 & 714 & 85 \\
\hline
\end{tabular}




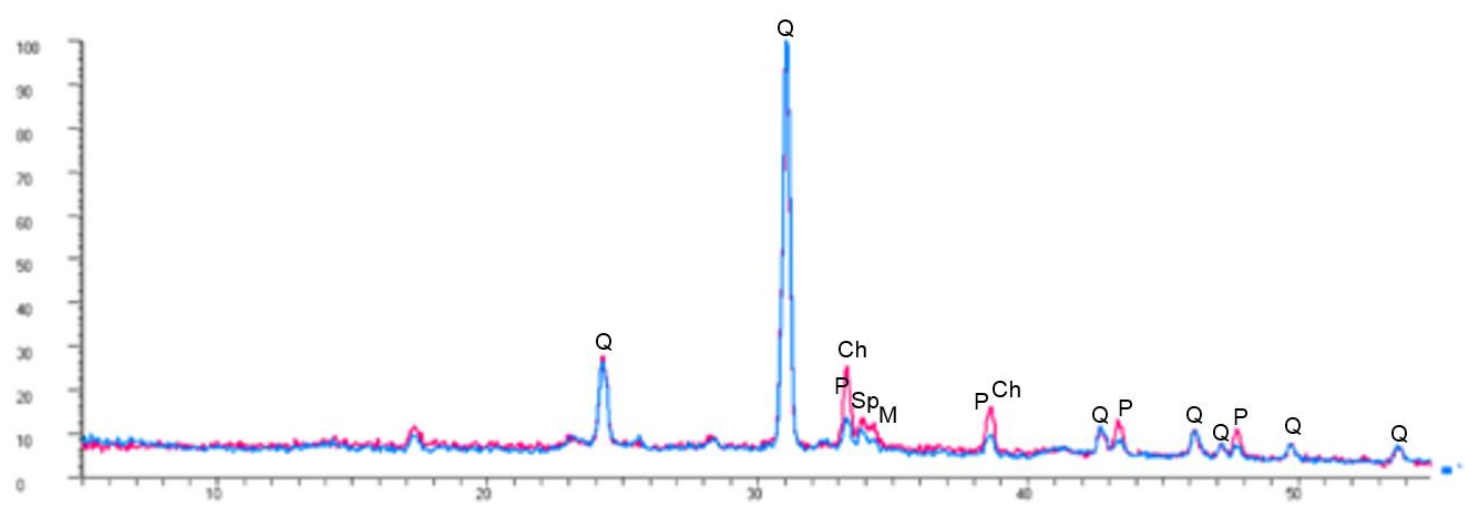

Figure 3. X-ray Diffractogram, with the mineralogical species found in the leaching test samples: quartz $(\mathrm{Q})$, sphalerite $(\mathrm{Sp})$, pyrite $(\mathrm{P})$, mooihoekite $(\mathrm{M})$, chalcopyrite $(\mathrm{Ch})$.

Table 5. Major elements composition of the leaching test sample

\begin{tabular}{cccccccccc}
\hline Elements & $\mathrm{Au}$ & $\mathrm{Ag}$ & $\mathrm{Cu}$ & $\mathrm{Pb}$ & $\mathrm{Zn}$ & $\mathrm{Fe}$ & $\mathrm{As}$ & $\mathrm{S}$ & $\mathrm{Si}$ \\
\hline Concentration $(\mathrm{ppm})$ & 9.35 & 148 & 1.53 & 1.79 & 6.60 & 12.57 & 0.83 & 12.70 & 12.68 \\
\hline
\end{tabular}

Referring to the results of mineral and chemical composition, the test sample can be said to be refractory sulfide gold ore as it was characterized by the content of sulfide minerals such as arsenopyrite, pyrite and chalcopyrite. The chemical composition also indicates that the sulfide minerals was dominant. Refractory sulfide gold ore with such compositions, in which the gold present as a solid solution in a host of minerals such as arsenopyrite, can be effectively recovered only if the mineral matrix is decomposed (Marchevsky et al., 2013; Faraz et al., 2014).

\section{Effect of $\mathrm{NaNO}_{2}$ addition in direct cyanidation of gold}

Various quantities of sodium nitrite in solution $(0.8 ; 1.0 ; 1.2 ; 1.4 ; 1.6 ; 1.8 ; 2.0$ $\mathrm{mol} / \mathrm{L}$ ) were used to determine the effect of nitrite concentration on dissolved gold. On cyanidation, gold is dissolved to form some complex compounds as aurocyanide anion, $\mathrm{Au}(\mathrm{CN})_{2}^{-}$at $\mathrm{pH}$ values of about 10 (Figure 1) and the reaction equation is generally written as follows:

$\mathrm{Au}^{0}+2 \mathrm{CN}^{-} \rightarrow \mathrm{Au}(\mathrm{CN})_{2}^{-}+\mathrm{e}$.

For gold can be dissolved into aurocyanide anion from refractory sulfide gold ore, the sulfide minerals as host of minerals must be decomposed first. Referring to the sulfide mineral leaching with nitric acid, where the commonly reported leach reaction of a sulfide mineral with nitric acid in conjunction with sulfuric acid is shown below (Gok, 2010; Hu, Wang and Wei, 2012).

$3 \mathrm{FeAsS}_{+} 12 \mathrm{HNO}_{3}=3 \mathrm{FeAsO}_{4}+4 \mathrm{H}^{+}+2$ $\mathrm{SO}_{4}{ }^{2-}+10 \mathrm{NO} \uparrow+4 \mathrm{H}_{2} \mathrm{O}+\mathrm{S}^{\circ}$

$2 \mathrm{FeS}_{2}+10 \mathrm{HNO}_{3}=2 \mathrm{Fe}_{3}^{+}+2 \mathrm{H}^{+}+4 \mathrm{SO}_{4}^{2-}$

$+10 \mathrm{NO} \uparrow+4 \mathrm{H}_{2} \mathrm{O}$

As can be seen from the equations (2) and (3), the $\mathrm{NO}_{3}^{-}$then reacts with the mineral and oxidizes the sulfide to sulfuric acid and sulfur. In addition, nitric oxide gas, NO, is produced from the oxidation of sulfides. As this gas has a limited solubility in aqueous solutions, it tends to transfer out of solution.

Thus, the decomposition reaction of sulfide minerals which are shown equations (2) and (3), can be rearranged similarly for sodium nitrite to the solution conditions at $\mathrm{pH}$ above 10 (base solution), and refers to the basic reaction given in Figures 4 and 5 as follows,

$2 \mathrm{FeAsS}+4 \mathrm{NO}_{2}^{-}+2 \mathrm{OH}^{-}+5 \frac{1}{2} \mathrm{O}_{2}=2 \mathrm{Fe}^{2+}+$ $2 \mathrm{AsO}_{4}{ }^{3-}+2 \mathrm{SO}_{4}{ }^{2-}+4 \mathrm{NO} \uparrow+\mathrm{H}_{2} \mathrm{O}$.

$2 \mathrm{FeS}_{2}+4 \mathrm{NO}_{2}^{-}+2 \mathrm{OH}^{-}+5 \frac{1}{2} \mathrm{O}_{2}=2 \mathrm{Fe}^{2+}+$ $4 \mathrm{SO}_{4}^{2-}+4 \mathrm{NO} \uparrow+\mathrm{H}_{2} \mathrm{O}$. 


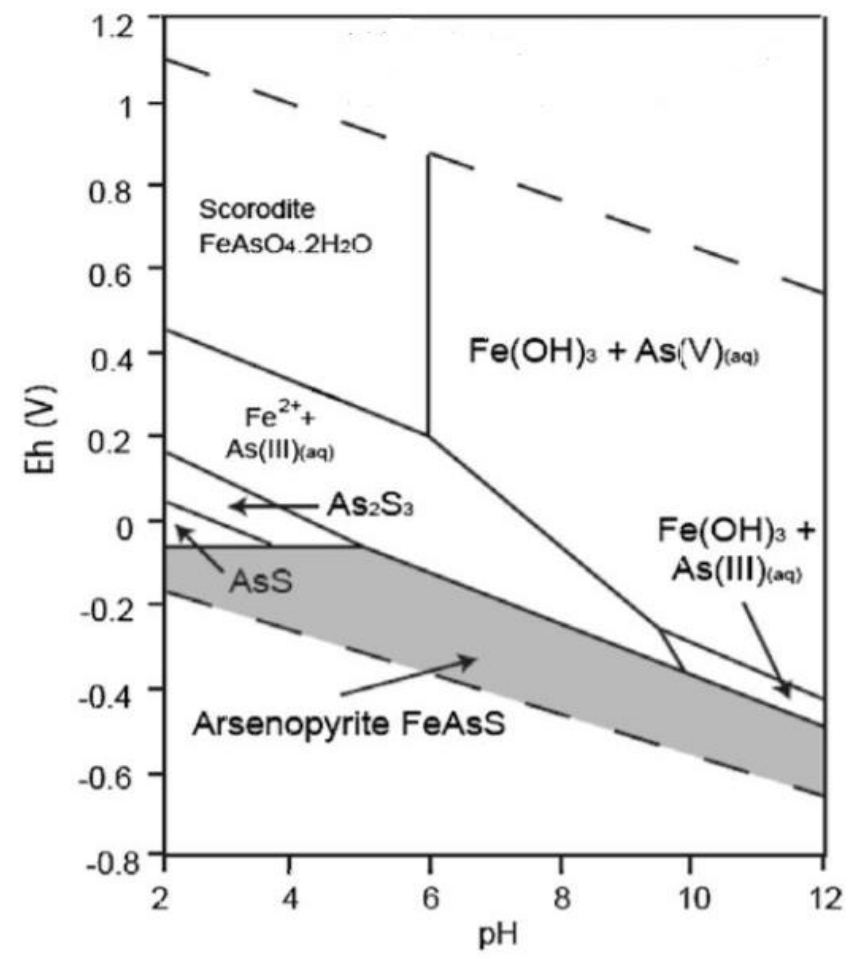

Figure 4. Eh-pH (Pourbaix) diagrams for the Fe-AS-S- $\mathrm{H}_{2} \mathrm{O}$ system at $25^{\circ} \mathrm{C}, 1 \mathrm{~atm}$.

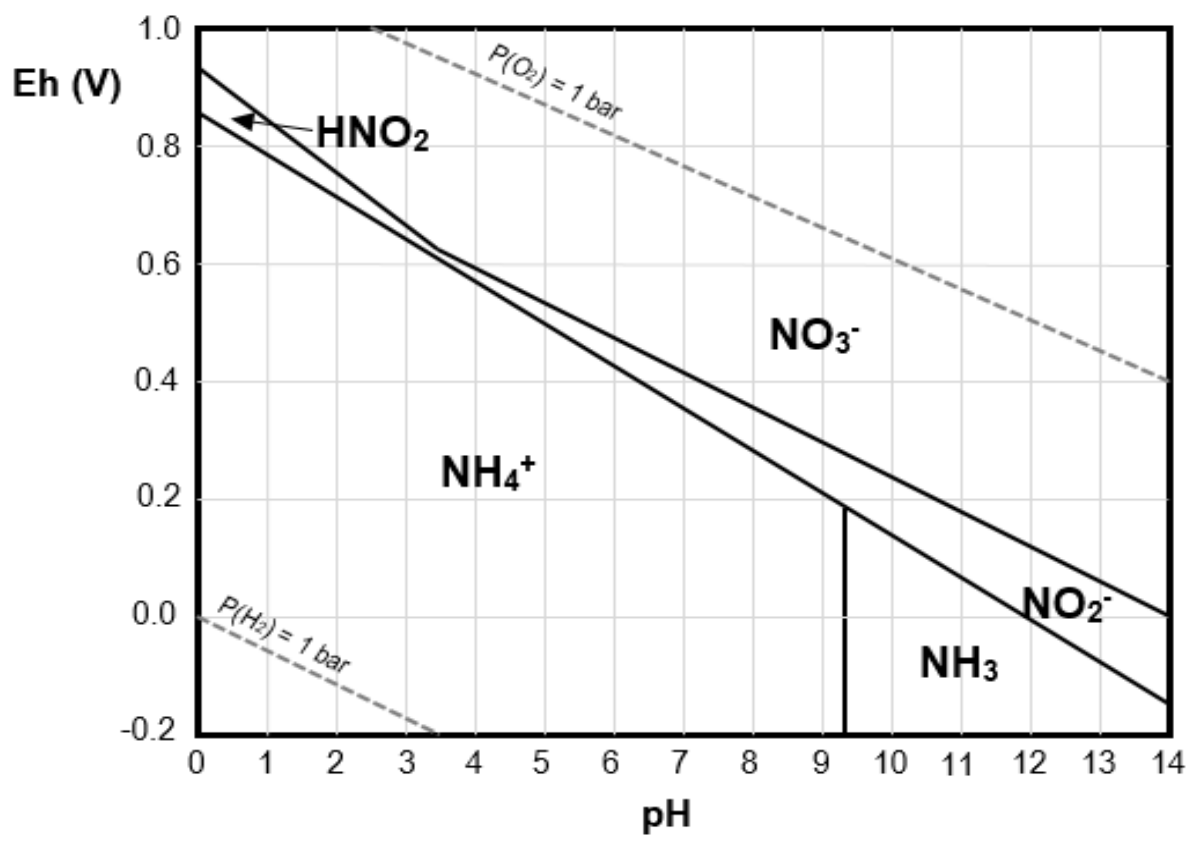

Figure 5. Eh-pH diagram of $\mathrm{N}$ representing its various forms at $25^{\circ} \mathrm{C}$ (Gok, 2010)

From the thermodynamic analysis of the reaction as presented in Figures 4 and 5, leach reaction of sulfide mineral with sodium nitrite in conjunction with sulfate, oxygen gas flow was required for decomposition reactions to be occurred. The use of nitrite as the oxidant has a higher oxidative level from the nitric as the oxidant to compare half-cell potential value as presented in Table 6. 
The obtained results presented in Figure 6 show the influence of the initial concentration of sodium nitrite in direct cyanidation of refractory sulfide gold ore through observing the characteristics of the dissolved of gold and silver. There was a slight increase in the gold leaching recovery with the addition of sodium nitrite from $0.8 \mathrm{M}$ to $1.4 \mathrm{M}$, but there is no change improvement for further additions. Sodium nitrite addition of $1.4 \mathrm{M}$ to 2.0 $\mathrm{M}$ did not affect gold extraction from the ore. Dissolution of gold was observed no occur an increasing again until the addition of $2.0 \mathrm{M}$.
For silver, the effect of sodium nitrite addition on the dissolution characteristics of silver shows a different result. Leaching recovery of silver was observed with obtaining $46.2 \%$ on initial addition of $0.8 \mathrm{M}$ of sodium nitrite. Further additions of sodium nitrite up to $2.0 \mathrm{M}$, did not enhance the recovery of silver, but can be said to be constant which at the addition of $1.2 \mathrm{M}$ sodium nitrite is obtained silver recovery of $47.0 \%$ and by the addition of $2.0 \mathrm{M}$ sodium nitrite, silver recovery obtained at $45.0 \%$.

Table 6. Relative potentials of hydrometallurgical oxidizers (Anderson, 2008)

\begin{tabular}{lll}
\hline \multicolumn{1}{c}{ Oxidant } & \multicolumn{1}{c}{ Redox Equation } & $\mathrm{E}^{\circ} \mathrm{h}\left(\mathrm{pH}=0, \mathrm{H}_{2}\right.$ ref. $)$ \\
\hline $\mathrm{Fe}^{+3}$ & $\mathrm{Fe}^{+3}+\mathrm{e}-\rightarrow \mathrm{Fe}$ & $0.770 \mathrm{~V}$ \\
$\mathrm{HNO}_{3}$ & $\mathrm{NO}_{3}^{-2}+4 \mathrm{H}^{+}+3 \mathrm{e}-\rightarrow \mathrm{NO}+2 \mathrm{H}_{2} \mathrm{O}$ & $0.957 \mathrm{~V}$ \\
$\mathrm{HNO}_{2}$ & $\mathrm{NO}_{2}-2 \mathrm{H}++\mathrm{e}-\rightarrow \mathrm{NO}+\mathrm{H}_{2} \mathrm{O}$ & $1.202 \mathrm{~V}$ \\
$\mathrm{O}_{2(\mathrm{~g})}$ & $\mathrm{O}_{2}+4 \mathrm{H}^{+}+4 \mathrm{e}-\rightarrow 2 \mathrm{H}_{2} \mathrm{O}$ & $1.230 \mathrm{~V}$ \\
$\mathrm{Cl}_{2(\mathrm{~g})}$ & $\mathrm{Cl}_{2(\mathrm{~g})}+2 \mathrm{e}-\rightarrow 2 \mathrm{Cl}^{-}$ & $1.358 \mathrm{~V}$ \\
$\mathrm{NO}^{+}$ & $\mathrm{NO}^{+}+\mathrm{e}-\mathrm{NO}$ & $1.450 \mathrm{~V}$ \\
\hline
\end{tabular}

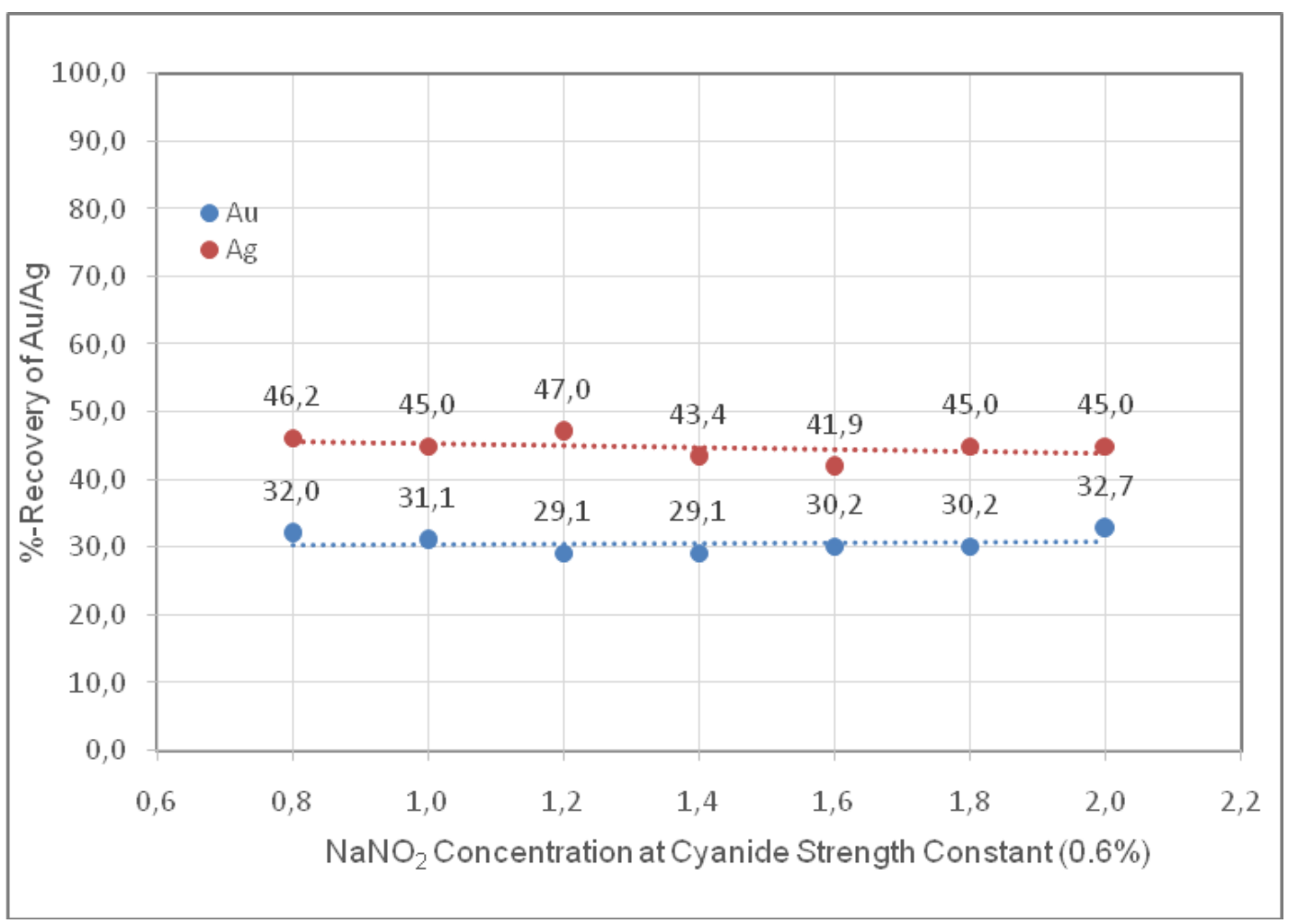

Figure 6 . Effect of sodium nitrite addition on recovery of gold at $0.6 \%-\mathrm{CN}$ constant 


\section{Effect of $\mathrm{NaCN}$ concentration on direct cyanidation of gold}

According to the results in Figure 6, it was shown that for all the leaching test, when the oxidant of sodium nitrite was added on direct cyanidation of refractory sulfide gold ore, it did not give a significant improvement result. To investigate the effect of cyanide strength from $0.8 \%$ up to $1.8 \%$ with the concentration of sodium nitrite was kept approximately constant over $1.2 \mathrm{M}$ and $1.4 \mathrm{M}$. The results are presented in Figures 7 and 8. The influence of cyanide strength on the recovery of gold dissolution has been observed more distinctly during leaching in $1.2 \mathrm{M}$ and $1.4 \mathrm{M}$ of sodium nitrite addition.

The effect of cyanide strength value on gold recovery was investigated by keeping sodium nitrite addition at $1.2 \mathrm{M}$. The results are plotted in Figure 7. It can be seen that increasing cyanide strength value was effectively dissolved gold from the ore. By increasing the cyanide strength value from $0.8 \%$ to $1.2 \%$, the recovery of gold increased dramatically from $66.3 \%$ to $76.7 \%$. A further increase in cyanide strength did not provide a significant effect on the gold leaching recovery. There was a slight decrease in the gold leaching recovery with the addition of cyanide strength from $1.4 \%$ to $1.8 \%$. At $1.4 \%$ of cyanide strength value, the gold recovery was $76.7 \%$ and $75.8 \%$ of gold recovery at $1.8 \%$ of cyanide strength value. In this condition of direct leaching of refractory sulfide gold ore at $1.2 \%$ of cyanide strength value and $1.2 \mathrm{M}$ of sodium nitrite addition has achieved an optimal gold extraction.

As observed from Figure 8, by increasing the sodium nitrite addition to $1.4 \mathrm{M}$ for investigating the effect of cyanide strength value on gold recovery on the direct leaching of refractory sulfide gold ore, experiments were carried out with similarly varying initial value of cyanide strength (from $0.8 \%$ to $1.8 \%$ ) and the obtained results are shown in Figure 8 it is obvious that sodium nitrite addition has a significant impact on gold recovery in the direct leaching of refractory sulfide gold ore. Recovery of gold increases with the rise in the concentration of sodium nitrite in the range considered in this study.

The influence of sodium nitrite concentration has shown a significant increase in the recovery gold leaching in general for all value cyanide strength observed. By reviewing simultaneously Figures 7 and 8, recovery of gold leaching at the addition of sodium nitrite of $1.2 \mathrm{M}$ increased gradually to its maximum value of $93.05 \%$ as the value of cyanide strength was increased from $0.8 \%$ to $1.2 \%$ (Figure 8). If it is viewed from changing the concentration of sodium nitrite addition of 1.2 $\mathrm{M}$ to $1.4 \mathrm{M}$, the recovery of gold leaching showed a significant increase from $76.70 \%$ to $93.05 \%$ at $1.2 \%$ of cyanide strength value.

\section{Characterization of the leach residue}

In order to identify the mineralogical changes brought about by leaching, solid residue from several leaching experiments at various levels of gold extraction was characterized by XRD analyses. The results were compared with the mineralogy of the original concentrate. The residue resulted from the following leaching conditions: $1.4 \mathrm{M}$ $\mathrm{NaNO}_{2}+0.8 \% \quad \mathrm{KCN} ; 1.4 \mathrm{M} \quad \mathrm{NaNO}_{2}+1.2 \%$ $\mathrm{KCN}$; and $1.4 \mathrm{M} \mathrm{NaNO}+1.8 \% \mathrm{KCN}$ with the gold recovery of $78.07 \%, 93.05 \%$ and $86.84 \%$ respectively were examined.

The results of the XRD analysis were presented in Figure 9. The XRD pattern of leach residue shown in Figure 9 indicates that a quartz mineralogical phase was more dominant and some chalcopyrite peak missing were observed together with other major phases identified in the original concentrate.

The leach residue with cyanide strength of $1.2 \%$ and $1.8 \%$ had a similar peak pattern that dominated by quartz. Its appearance was different with XRD pattern of leach residue with $0.8 \%$ cyanide strength where the peaks of chalcopyrite and pyrite disappeared compared to an original sample. Meanwhile, the gold recovery increased to $93.04 \%$. This represents the ultimate possible recovery of gold from fully oxidized concentrate.

The information, concerning the concentrate and the residue, is given in Figure 9. It can be seen that the major phases found in the concentrate were upgraded and not leached. This result confirms that other sulfide minerals in the concentrate remain insoluble for sphalerite both in concentrates and leach residue. 
INDONESIAN MINING JOURNAL Vol. 19, No. 3, October $2016: 153$ - 165

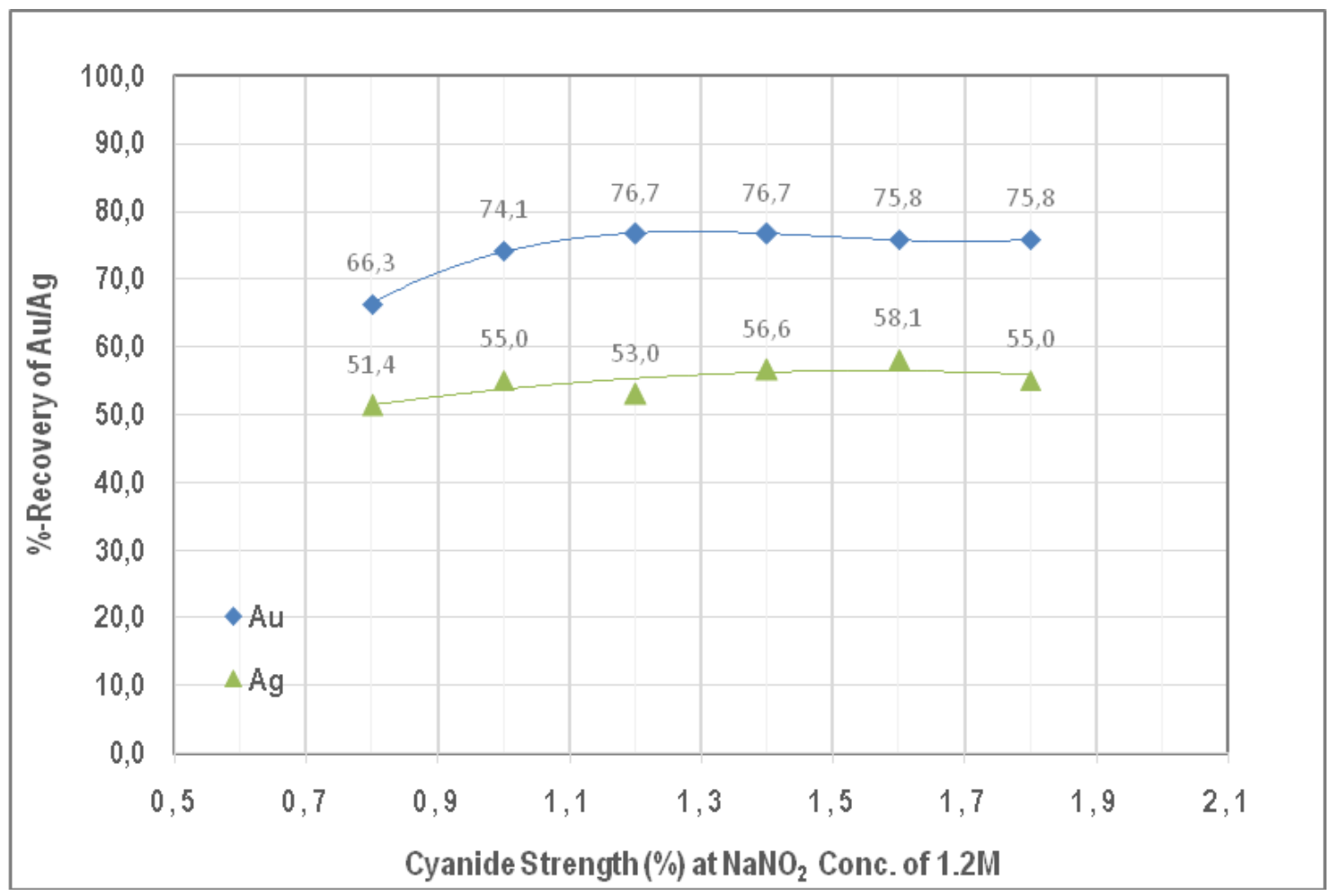

Figure 7. Influence of cyanide strength value on gold recovery at $1.2 \mathrm{M}$ of $\mathrm{NaNO}_{2}$

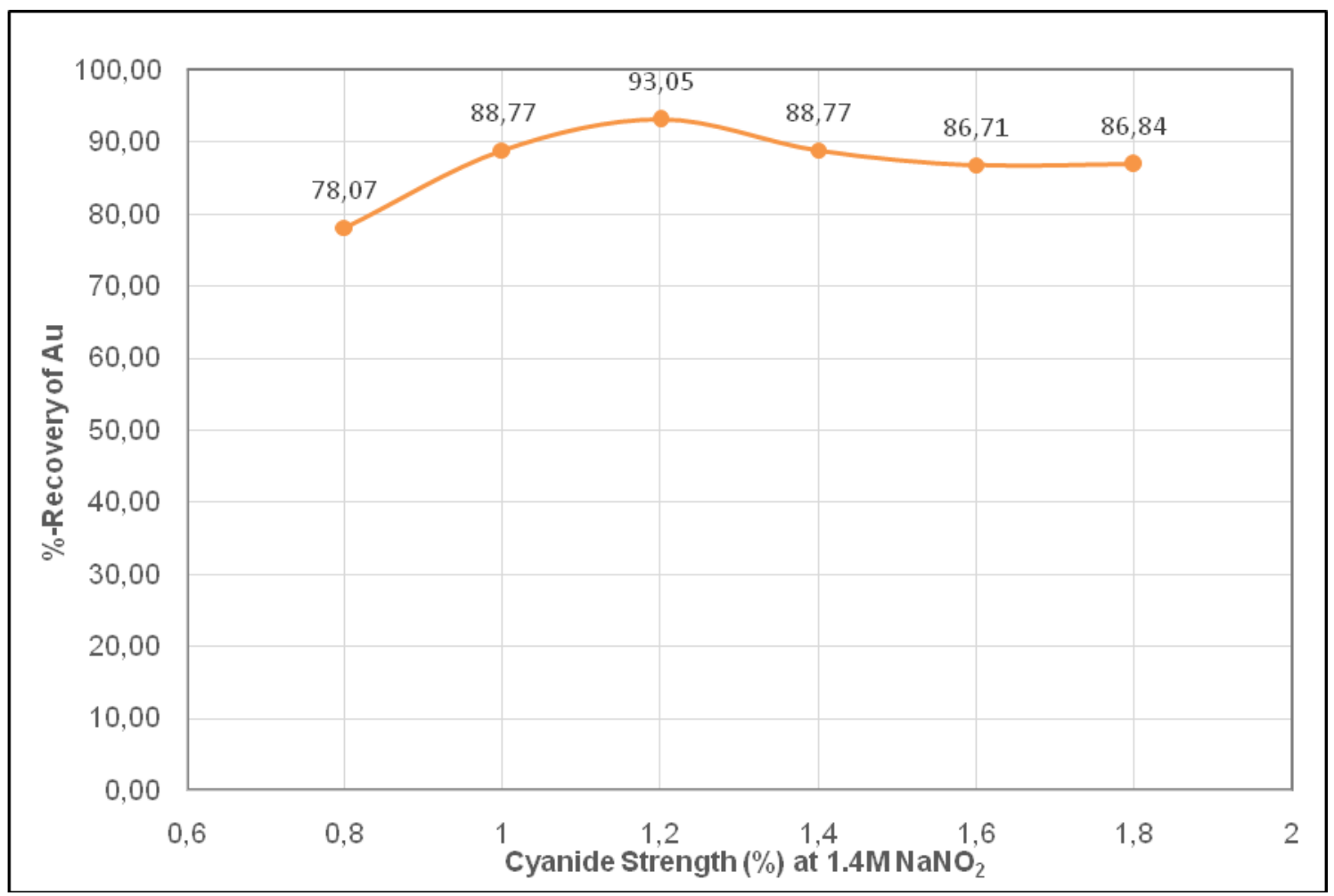

Figure 8. Influence of cyanide strength value on gold recovery in $1.4 \mathrm{M}$ of $\mathrm{NaNO}_{2}$ addition 


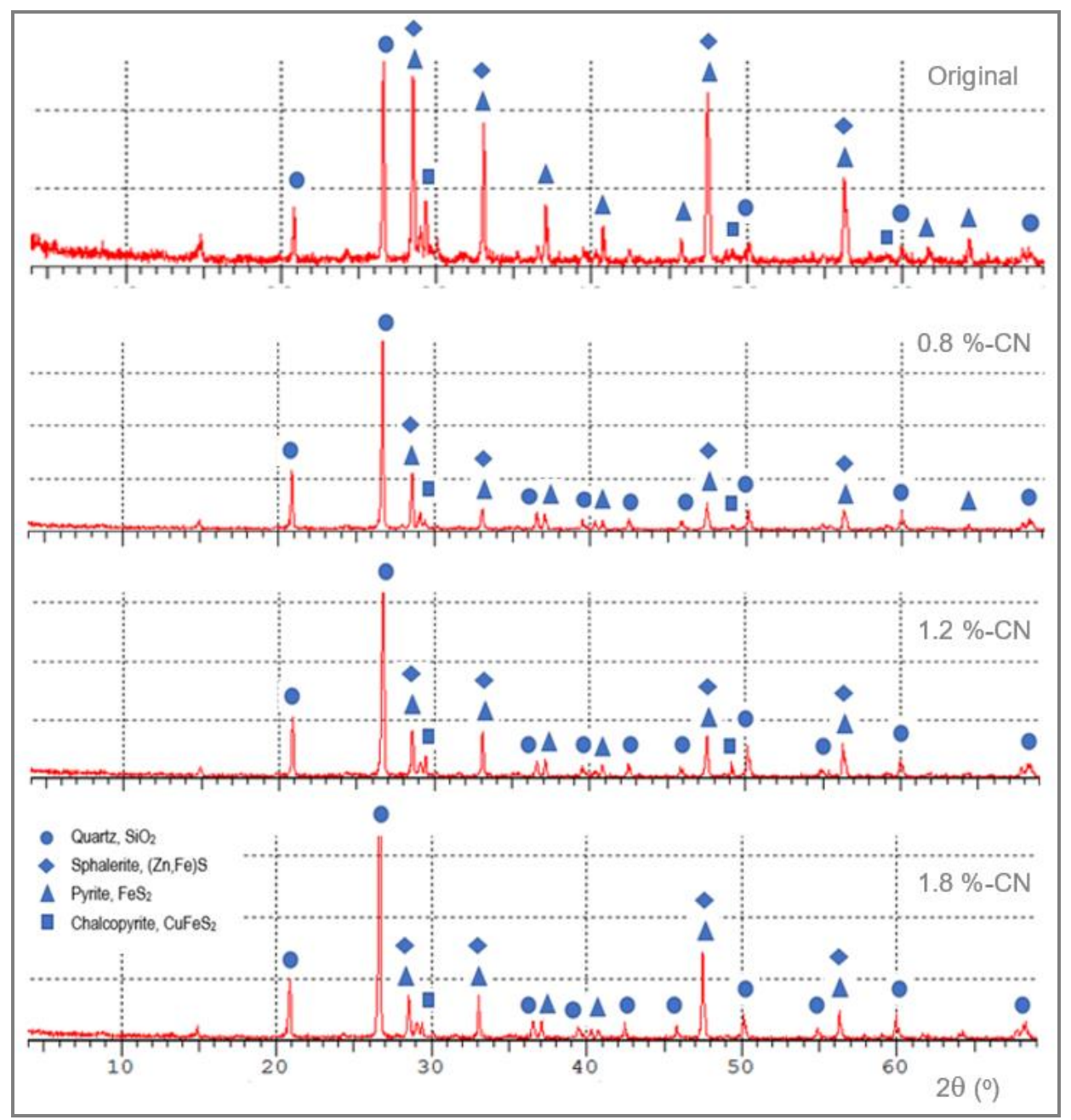

Figure 9. XRD pattern of a typical leach residue at $1.4 \mathrm{M} \mathrm{NaNO}_{2}$ addition, and original

\section{CONCLUSION AND SUGGESTION}

This paper describes the effect of sodium nitrite as an oxidative reagent on cyanidation of refractory gold ore. The results showed that sodium nitrite addition had a significant effect on gold and silver extractions from refractory ore. Increasing the cyanide strength also enhanced the recovery of gold significantly. These findings suggest that application of a suitable pretreatment method is required to improve $\mathrm{Au} / \mathrm{Ag}$ extraction, and this study has a potential for playing an increasing future role in the pretreatment option of refractory gold ore processing.

\section{ACKNOWLEDGEMENT}

The author would like to acknowledge the $\mathrm{R}$ \& D Centre for Mineral and Coal Technology for its financial support to this study. To thanks also to PT USA, West Java for providing eefractory gold concentrates samples used in this study. The author also wishes to express an appreciation to Ir. Tatang Wahyudi, M.Sc. - a Senior Researcher at RDCMTC - for his his valuable insight and criticism which improved the quality of this manuscript.

\section{REFERENCES}

Anderson, C. G. (2008) 'NSC pressure leaching: industrial and potential applications', in Young, C. A. et al. (eds) Hydrometallurgy 2008: Proceedings of the Sixth International Symposium. Society for Mining, Metallurgy, and Exploration, Inc., pp. 858-884.

Anonymous (2012) 'Recovering refractory resources', www.miningmagazine.com, September, pp. 148-160. 
Asamoah, R., Amankwah, R. K. and AddaiMensah, J. (2014) 'Cyanidation of refractory gold ores: A review', in 3rd UMaT Biennial International Mining and Mineral Conference. Tarkwa, Ghana, pp. 204-212. doi: 10.13140/2.1.4772.6407.

Badri, R. and Zamankhan, P. (2013) 'Sulphidic refractory gold ore pre-treatment by selective and bulk flotation methods', Advanced Powder Technology, 24(2), pp. 512-519. doi: 10.1016/j.apt.2012.10.002.

Breuer, P. (2015) 'Dealing with copper gold ores: Implemented and future approaches', in ALTA-2015 Gold Precious Metals Proceedings. Melbourne, Australia: ALTA Metallurgical Services Publications, pp. 2-20.

Carrillo-Pedroza, F. R. et al. (2012) 'Oxidative Hydrometallurgy of Sulphide Minerals', in Nusheh, M., Ahuett, H. G., and Arrambide, A. (eds) Recent Researches in Metallurgical Engineering - From Extraction to Forming. InTech, pp. 2540. doi: $10.5772 / 36107$.

Faraz, S. et al. (2014) 'Improved recovery of a lowgrade refractory gold ore using flotationpreoxidation-cyanidation methods', International Journal of Mining Science and Technology, 24(4), pp. 537-542. doi: 10.1016/j.jmst.2014.05.018.

Gok, O. (2010) 'Oxidative leaching of sulfide ores with the participation of nitrogen species - A review', Journal of Ore Dressing, pp. 22-29.

Gökelma, M. et al. (2016) 'A review on alternative gold recovery re-agents to cyanide', Journal of Materials Science and Chemical Engineering, 4(8), pp. 8-17. doi: 10.4236/msce.2016.48002.

Hasab, M. G., Rashchi, F. and Raygan, S. (2013) 'Simultaneous sulfide oxidation and gold leaching of a refractory gold concentrate by chloride-hypochlorite solution', Minerals Engineering, 50-51, pp. 140142. doi: 10.1016/j.mineng.2012.08.011.

Hu, S. R., Wang, C. and Wei, Q. F. (2012) 'The oxidation pretreatment of a sulfidic refractory gold ore with pyrolusite', Advanced Materials Research, 550-553, pp. 2891-2894. doi: 10.4028/www.scientific.net/AMR.550553.2891 .
Khoshnevisana, A. and Yoozbashizadeha, $\mathrm{H}$. (2012) 'Determination of optimal conditions for pressure oxidative leaching of sarcheshmeh molybdenite concentrate using Taguchi method', Journal of Mining and Metallurgy, Section B: Metallurgy, 48(1), pp. 89-99. doi: 10.2298/JMMB110308003K.

Li, D.-X. (2009) 'Developments in the pretreatment of refractory gold minerals by nitric acid', in World Gold Conference 2009. The Southern African Institute of Mining and Metallurgy, pp. 145-150.

$\mathrm{Li}$, J. et al. (2006) 'The influence of pyrite preoxidation on gold recovery by cyanidation', Minerals Engineering, 19(9), pp. 883-895. doi: 10.1016/j.mineng.2005.09.052.

Marchevsky, N. et al. (2013) 'Recovery of zinc during the pre-treatment of a refractory gold-bearing ore', Advanced Materials Research, 825, pp. 431-434. doi: 10.4028/www.scientific.net/AMR.825.43 1.

Marsden, J. O. and House, C. I. (2009) The chemistry of gold extraction. 2nd Editio. Society for Mining, Metallurgy, and Exploration, Inc.

McHugh, L. F., Balliett, R. and Mozolic, J. A. (2008) 'The sulfide ore looping oxidation process: An alternative to current roasting and smelting practice', JOM, 60(7), pp. 84-87. doi: 10.1007/s11837008-0097-9.

Mesa Espitia, S. L. and Lapidus, G. T. (2015) 'Pretreatment of a refractory arsenopyritic gold ore using hydroxyl ion', Hydrometallurgy, 153, pp. 106-113. doi: 10.1016/j.hydromet.2015.02.013.

De Michelis, I. et al. (2013) 'Roasting and chlorine leaching of gold-bearing refractory concentrate: Experimental and process analysis', International Journal of Mining Science and Technology, 23(5), pp. 709-715. doi: 10.1016/j.jimst.2013.08.015.

Muravyov, M. I., Fomchenko, N. V. and Kondrat'eva, T. F. (2015) 'Investigation of steps of ferric leaching and biooxidation at the recovery of gold from sulfide concentrate', Applied Biochemistry and Microbiology, 51(1), pp. 75-82. doi: $10.1134 /$ S0003683815010111. 
Recovery of Refactory Sulfide Concentrates Using Direct Cyanide ... Suratman

Valenzuela, A., Valenzuela, J. L. and Parga, J. R. (2013) 'Effect of pretreatment of sulfide refractory concentrate with sodium hypochlorite, followed by extraction of gold by pressure cyanidation, on gold removal', Advances in Chemical Engineering and Science, 3(3), pp. 171177. doi: 10.4236/aces.2013.33021. 
